\title{
Changing Course*
}

Sergio J. Campos**

\section{INTRODUCTION}

In a recent address at a meeting of the International Bar Association in Washington, D.C., Justice Anthony Kennedy told the audience that "[t]o re-examine your premise is not a sign of weakness of your judicial philosophy. It's a sign of fidelity to your judicial oath." The Associated Press report of the address speculated that Justice Kennedy's words "sounded like a partial explanation of his votes in two recent cases involving race, in which he uncharacteristically sided with liberal justices." 2

Whatever the motivation for Justice Kennedy's remarks, I do perceive a recent change of course in his views in at least one area of the law-civil procedure. This symposium celebrates the fiftieth anniversary of the 1966 amendments to the Federal Rules of Civil Procedure, particularly the amendments to Rule 23, the class action rule. The 1966 amendments to Rule 23 sought self-consciously "to shake the law of class actions free of abstract categories ... and to rebuild the law on functional lines responsive to those recurrent life patterns which call

\footnotetext{
* This essay was written for a symposium celebrating the 1966 amendments to Rule 23, the federal class action rule. It argues that, in his recent decisions, Justice Kennedy appears to be shifting his thinking on the relationship between substance and procedure, particularly in the class action context. I argue that this shift is worth celebrating and is consistent with the functional concerns that animated the 1966 amendments.

** Professor of Law, University of Miami School of Law. I want to thank Owen Fiss, Pat Gudridge, Leah Litman, Steve Schnably, Adam Steinman, and Adam Zimmerman for their comments and conversation. I also want to thank participants at a workshop at the University of Alabama School of Law for their thoughts and suggestions on a previous draft. Hailey Blanco, Sarah J. Cohen, and Alyssa D'Bazo provided excellent research assistance. I acknowledge that I participated in an amicus brief in a case discussed in this article-Tyson Foods, Inc. v. Bouaphakeo, 136 S. Ct. 1036 (2016). However, I received no compensation for my work on this brief and the views express here are solely my own. Of course, all errors are mine.

1. Mark Sherman, Justice: Changing Course on the Bench Is Not Weakness, AP NEws (Sept. 23, 2016), https://apnews.com/93476b06b78c409393f38df4d5d507b7 (last visited Mar. 17, 2017).

2. Id. The "two recent cases" referred to in the article are Fisher v. Univ. of Tex. at Austin, 136 S. Ct. 2198 (2016) and Tex. Dep't of Hous. \& Cmty. Affairs v. Inclusive Cmtys. Project, Inc., 135 S. Ct. 2507 (2015). Id.
} 
for mass litigation through representative[s]." ${ }^{, 3}$ Although it is unclear whether the 1966 amendments to Rule 23 were successful, ${ }^{4}$ they were certainly consequential, as they gave birth to the modern class action.

I perceive a similar, albeit not as seismic, shift in Justice Kennedy's views on the relationship between substance and procedure. As recently as six years ago, Justice Kennedy held a view of due process that, like Rule 23 prior to the 1966 amendments, was based on an "abstract" picture of procedure that ignored substantive matters like policy or fairness. ${ }^{5}$ But in his most recent decisions involving the class action ${ }^{6}$ and other procedural matters, ${ }^{7}$ Justice Kennedy has adopted a more functional view of procedure in which procedures should "respon[d] to those recurrent life patterns" that arise in different substantive contexts. ${ }^{8}$

Of course, what I perceive to be a change of course may simply be an outlier in Justice Kennedy's overall views of procedure, or may be consistent with those views properly understood. Any change may also reflect two different strands of Justice Kennedy's thinking on procedure that have yet to be reconciled. Accordingly, this essay does not in any way purport to present a comprehensive or exhaustive account of Justice Kennedy's views on procedure. Instead, I focus on Justice Kennedy's views in the past six years or so, in which a change of course has been noticeable, at least to me. Whether any shift represents no shift at all, a reversion to the mean, or an unstable hybrid, I leave to constitutional law scholars.

Nevertheless, to borrow Justice Kennedy's terms, I do perceive in his recent decisions a "re-examin[ation]" of certain "premise[s]" concerning the relationship of procedure to the substantive law. ${ }^{9}$ And, in my view, this re-examination is worth exploring, even celebrating, on the fiftieth anniversary of the modern class action.

In this short essay I discuss what I perceive to be Justice Kennedy's prior view of the relationship between substance and procedure, and the

3. Benjamin Kaplan, A Prefatory Note, 10 B.C. Indus. \& CoM. L. Rev. 497, 497 (1969). Ben Kaplan was the reporter for the 1966 amendments.

4. See Robert G. Bone, Walking the Class Action Maze: Toward a More Functional Rule 23, 46 U. MiCH. J. L. REFORM 1097, 1103-05 (2013) (arguing that they were not).

5. See generally J. McIntyre Machinery, Ltd. v. Nicastro, 564 U.S. 873 (2011).

6. See generally Tyson Foods, Inc. v. Bouaphakeo, 136 S. Ct. 1036 (2016).

7. E.g., Hollingsworth v. Perry, 133 S. Ct. 2652, 2668 (2014) (Kennedy, J., dissenting) (discussing Article III standing).

8. Kaplan, supra note 3, at 497.

9. This essay is an offshoot of a much larger project on the Supreme Court's recent class action decisions. See Sergio J. Campos \& Adam Zimmerman, The Class Action Awakens (March 8, 2017) (unpublished manuscript) (on file with author). 
more recent view on that relationship he has expressed in his more recent opinions. I conclude by suggesting that Justice Kennedy's shifting views are not only a welcome departure, but can be understood as throwback to the "functional" approach that motivated the 1966 amendments.

\section{JUSTICE KENNEDY AND THE IDEAL OF PROCEDURE}

\section{A. Personal Jurisdiction}

To understand why I perceive a recent change of course in Justice Kennedy's views on procedure, one need only look at his plurality opinion in J. McIntyre Machinery, Ltd. v. Nicastro. Decided in 2011, Nicastro involved a state law products liability action brought by a scrap metal worker who "seriously injured his hand using a metal-shearing machine manufactured by [the defendant]." 10 At issue was whether New Jersey state courts could exercise personal jurisdiction over the defendant J. McIntyre Machinery, Ltd. (McIntyre), who was based in England and who had an arm's-length arrangement with the American distributor who sold the machine in the case. ${ }^{11}$ Moreover, although McIntyre advertised its machines in the United States, it never expressly targeted the New Jersey market, instead directing its marketing materials to the U.S. market as a whole. ${ }^{12}$

Nicastro raised the issue of whether an out-of-state defendant could be haled into a U.S. court based on a product reaching the forum through the stream of commerce. In a series of cases decided in the 1980 s the Court struggled with applying the modern standard for personal jurisdiction, first articulated in International Shoe, ${ }^{13}$ to such stream-ofcommerce cases. In International Shoe the Court broke from its earlier approach to personal jurisdiction, which focused on an out-of-state defendant's presence in the forum state. ${ }^{14}$ Such a move was understandable given the great lengths the defendant in International Shoe went to in order to do business in the state of Washington without being "present within the state." 15 For example, the defendant (1) did not keep any shoe inventory in the state, (2) rented "rooms in hotels or business buildings temporarily" to show samples, and (3) only gave its

0. Nicastro, 564 U.S. at 878.

11. Id.

12. Id. at $878-79$.

13. Int'l Shoe Co. v. Wash., 326 U.S. 310, 316 (1945).

14. See Pennoyer v. Neff, 95 U.S. 714, 733 (1877).

15. Int'l Shoe, 326 U.S. at 316-17. 
salesmen samples "consisting of one shoe of a pair."16 Instead of looking at a defendant's "presence" in the forum state, the Court instead focused on whether the defendant's "minimum contacts" with a forum permitted the exercise of jurisdiction such that a forum court would not offend "traditional notions of fair play and substantial justice." 17 This "minimum contacts" test has since become the standard for ascertaining when a court may exercise personal jurisdiction over a nonconsenting defendant. ${ }^{18}$

Since International Shoe, and with a few exceptions, ${ }^{19}$ there has been some consensus that, as far as "minimum contacts" go, the defendant must "purposefully avail[] itself of the privilege of conducting activities within the forum State, thus invoking the benefits and protections of its laws." 20 For example, a forum could not exercise jurisdiction simply because the product inadvertently appeared in the forum through the "unilateral activity" of the consumer. ${ }^{21}$

But there was disagreement as to how much "purposeful availment" was necessary in stream-of-commerce cases. In World-Wide Volkswagen Corp. v. Woodson, decided in 1980, a majority of the Court suggested in dicta that a forum could exercise jurisdiction over an out-ofstate defendant if the defendant "deliver[ed] its products into the stream of commerce with the expectation that they will be purchased by consumers in the forum State."22 Seven years later, in Asahi Metal Industry Co., Ltd. v. Superior Court, at least four justices continued to hold this view. ${ }^{23}$ However, four other justices in Asahi believed that more than merely placing a product in the "stream of commerce" was necessary. Instead, the defendant must act in way that is "purposefully directed toward the forum State" beyond having an "awareness that the stream of commerce may or will sweep the product into the forum State." 24

\footnotetext{
16. Id. at $313-14$.

17. Id. at 316 .

18. See Shaffer v. Heitner, 433 U.S. 186, 207 (1977) (“The standard for determining whether an exercise of jurisdiction over the interests of persons is consistent with the Due Process Clause is the minimum-contacts standard elucidated in International Shoe.").

19. See McGee v. Int'l Life Ins. Co., 355 U.S. 220, 223-24 (1957) (permitting the exercise of personal jurisdiction based solely on maintaining a single insurance policy in the forum).

20. Hanson v. Denckla, 357 U.S. 235, 253 (1958).

21. World-Wide Volkswagen Corp. v. Woodson, 444 U.S. 286, 298 (1980).

22. $I d$.

23. 480 U.S. 102, 118-20 (1987) (Brennan, J., concurring in part and concurring in judgment).

24. Id. at 112 .
} 
There was also disagreement as to the role "traditional notions of fair play and substantial justice" play in stream-of-commerce cases. On the one hand, despite the disagreement on minimum contacts, eight of the nine justices in Asahi agreed that the exercise of jurisdiction would offend such traditional notions because, among other things, both the plaintiff and defendant were foreign companies based in East Asia, and neither party (or the state for that matter) had any real interest in resolving their dispute in California state court. ${ }^{25}$ Indeed, Justice O'Connor, writing for all but one justice, quoted Volkswagen in identifying five factors for determining whether a court's exercise of personal jurisdiction violated such "traditional notions": "[1] the burden on the defendant, [2] the interests of the forum State,... [3] the plaintiff's interest in obtaining relief... [4] 'the interstate judicial system's interest in obtaining the most efficient resolution of controversies; and [5] the shared interest of the several States in furthering fundamental substantive social policies.",26

However, the lone justice who did not join this "traditional notions" holding in Asahi, Justice Scalia, would later express his view of the role of the "traditional notions" analysis in a non-stream-of-commerce case, Burnham v. Superior Court. ${ }^{27}$ There, Justice Scalia concluded that a focus on "traditional notions" should jettison substantive considerations like the five Volkswagen/Asahi factors altogether and instead focus on those minimum contacts which "traditionally" were considered sufficient. ${ }^{28}$ In other words, personal jurisdiction should be based solely on traditionally recognized "minimum contacts" like personal service in the forum state, and not on "each Justice's subjective assessment of what is fair and just." 29

The consequence of Justice Scalia's rejection of an independent fairness inquiry concerning the exercise of personal jurisdiction is that it prioritized certain procedures regardless of their substantive impact. Justice Scalia's view was ostensibly based on the "subjectivity, and hence inadequacy" of using the "traditional notions" prong of the test to assess the overall fairness of the exercise of jurisdiction. ${ }^{30}$ But it also

25. Id. at 113-16 (noting "the international context, the heavy burden on the alien defendant, and the slight interests of the plaintiff and the forum State").

26. Id. at 113 (quoting Volkswagen, 444 U.S. at 292).

27. 495 U.S. 604 (1990). Burnham concerned whether a California state court could exercise jurisdiction over a New Jersey resident who was served a divorce petition in California while visiting his children after a separation from his spouse. Id. at 607-08.

28. Id. at 621-23.

29. Id. at 623 .

30. Id. 
rested on a view of the supremacy of traditional procedures, remarking that " $[\mathrm{t}] \mathrm{h}$ e short of the matter is that jurisdiction based on physical presence alone constitutes due process because it is one of the continuing traditions of our legal system that define the due process standard of "traditional notions of fair play and substantial justice." "31 Nevertheless, whether out of judicial modesty or a reverence for tradition, Justice Scalia refused to consider the substantive impact of procedures like the exercise of personal jurisdiction.

Compare this approach to Justice Brennan, who championed the use of the "traditional notions" prong to independently assess the substantive impact of the exercise of personal jurisdiction. In a contract case decided shortly before Asahi, Burger King Corp. v. Rudzewicz, ${ }^{32}$ Justice Brennan noted, in particular, that "a forum legitimately may exercise personal jurisdiction over a nonresident" because, among other things, "[a] State generally has a 'manifest interest' in providing its residents with a convenient forum for redressing injuries inflicted by out-of-state actors." 33 Moreover, it may be unfair to allow a nonresident to escape the consequences of its actions when it has "purposefully derive[d] benefit" from the state. ${ }^{34}$ Whereas Justice Scalia ignored the substantive impact of procedures in justifying the exercise of personal jurisdiction, in Burger King Justice Brennan began with the substantive impact of exercising jurisdiction over nonresidents to justify the exercise of personal jurisdiction in certain cases. In fact, Justice Brennan further suggested that an independent inquiry into such substantive issues could "serve to establish the reasonableness of jurisdiction upon a lesser showing of minimum contacts than would otherwise be required." 35

It is against this background that the Court decided Nicastro in 2011, over thirty years after Volkswagen and over twenty years after Burnham. One issue in Nicastro concerned whether the "stream-of-commerce" theory of minimum contacts outlined in dicta in Volkswagen would command a majority on the Court, or whether Justice O'Connor's more stringent, "substantial connection" standard set forth in Asahi would prevail. $^{36}$ There was also the question of whether the Court would accept Justice Scalia's theory of "traditional notions," or Justice Brennan's much stronger version based on the substantive impact of any exercise of

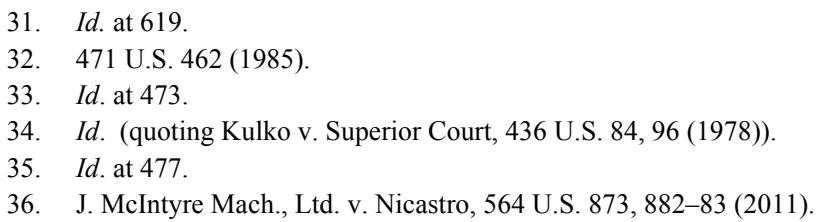


personal jurisdiction. Of course, by 2011, Justice Brennan was no longer on the Court, but Justice Scalia and his views remained. And it is hard not to detect the influence of Justice Scalia's views in Justice Kennedy's plurality opinion in Nicastro.

Justice Kennedy, writing for three other justices, including Justice Scalia, approached Nicastro in much the same way that Justice Scalia approached Burnham - by looking to history and tradition to determine the underlying principles that governed permissible exercises of personal jurisdiction. Indeed, Justice Kennedy stated up front that "[f]reeform notions of fundamental fairness divorced from traditional practice cannot transform a judgment rendered in the absence of authority into law."

Justice Kennedy concluded that appeals to such things as "presence" and "purposeful availment" in the prior case law reflect an insistence on "circumstances, or a course of conduct, from which it is proper to infer an intention to benefit from and thus an intention to submit to the laws of the forum State." 38 Accordingly, Justice Kennedy further concluded that, to determine whether the exercise of personal jurisdiction is appropriate in stream-of-commerce cases, "[t]he principal inquiry in cases of this sort is whether the defendant's activities manifest an intention to submit to the power of a sovereign." 39 In other words, a court must look at whether, through its actions, a defendant intends to submit itself to a forum's coercive power.

As for an independent "traditional notions" analysis, Justice Kennedy eschewed the five factors outlined in Volkswagen and Asahi. Noting that a plurality in Burnham "conducted no independent inquiry into the desirability or fairness" of personal jurisdiction in that case, Justice Kennedy pointed out that

[f] urthermore, were general fairness considerations the touchstone of jurisdiction, a lack of purposeful availment might be excused where carefully crafted judicial procedures could otherwise protect the defendant's interests, or where the plaintiff would suffer substantial hardship if forced to litigate in a foreign forum. That such considerations have not been deemed controlling is instructive. ${ }^{40}$

\footnotetext{
37. Id. at 880 (emphasis added).

38. Id. at 881 (emphasis added).

39. Id. at 882 .

40. Id. at 883-84 (citing World-Wide Volkswagen Corp. v. Woodson, 444 U.S. 286, 294 (1980)).
} 
This passage is remarkable for two reasons. First, the parties' interests were explicitly taken into account in both Volkswagen and Asahi, and were arguably "controlling." Indeed, Asahi commanded a majority because eight justices agreed that the interests of the plaintiff and defendant, among other things, did not support personal jurisdiction. Admittedly, Asahi involved prohibiting the exercise of jurisdiction, not the granting of jurisdiction in the absence of purposeful availment. But, just two years prior in Burger King, Justice Brennan, writing for a majority, did state that an inquiry into "traditional notions" "serve[s] to establish the reasonableness of jurisdiction upon a lesser showing of minimum contacts than would otherwise be required."41 Thus, it was far from clear that prior case law prevented such fairness considerations from justifying the exercise of personal jurisdiction in the absence of purposeful availment.

Second, the very concept of "traditional notions" introduced by the Court in International Shoe was designed to cast aside "fictions of implied consent" by giving fairness considerations weight, as pointed out by Justice Ginsburg in dissent, quoting, of all cases, Burnham. ${ }^{42}$ Indeed, the majority in International Shoe engendered a separate opinion from Justice Black, who, like Justice Scalia, was a textualist. ${ }^{43}$ In his opinion Justice Black criticized the International Shoe majority's use of the terms "fair play," "justice," and "reasonableness" by stating that "[n]o one, not even those who most feared a democratic government, ever formally proposed that courts should be given power to invalidate legislation under any such elastic standards." 44

Ultimately, Justice Kennedy's "manifest intent" standard did not garner a majority, and thus is not law. Indeed, in a concurrence Justice Breyer, joined by Justice Alito, expressed a concern that such a standard could lead to unjust results in cases involving internet retailers. ${ }^{45}$ But

41. Burger King Corp. v. Rudzewicz, 471 U.S. 462, 477 (1985) (emphasis added).

42. Nicastro, 564 U.S. at 900-01 (Ginsburg, J., dissenting) (citing, inter alia, Burnham v. Super. Ct., 495 U.S. 604, 618 (1990)).

43. See Michael J. Gerhardt, A Tale of Two Textualists: A Critical Comparison of Justices Black and Scalia, 74 B.U. L. REV. 25, 29 (1994) ("Both [Justices Black and Scalia] have espoused a theory of constitutional interpretation that requires judges to hew as closely as possible to constitutional text. Where the text is clear, this approach requires adhering to its plain meaning.").

44. Int'1 Shoe Co. v. Wash., 326 U.S. 310, 324-25 (opinion of Black, J.).

45. Nicastro, 564 U.S. at 890 (Breyer, J., concurring) ("But what do those standards mean when a company targets the world by selling products from its Web site? And does it matter if, instead of shipping the products directly, a company consigns the products through an intermediary (say, Amazon.com) who then receives and fulfills the orders? And what if the company markets its products through popup advertisements that it knows will be viewed in a forum? Those issues have serious commercial consequences but are totally absent in this case."). 
Justice Kennedy's plurality opinion did display a view that the substantive impact of a procedure is irrelevant to determining whether that procedure satisfies due process. In Nicastro, Justice Kennedy made clear that issues of personal jurisdiction implicate an individual's liberty interests under the Due Process Clause. ${ }^{46}$ Thus, one can infer from Justice Kennedy's opinion that the key to satisfying the due process concerns inherent in doctrines like personal jurisdiction is to intuit what ideal procedures have been permitted (in the case of personal jurisdiction, procedures that suggest implied consent), and not consider anything else.

\section{B. Class Actions}

Around the time of Nicastro, Justice Kennedy also strongly hinted that a similar "ideal procedure" view of due process informed his views of class actions. This is evidenced by a little seen opinion he authored concurring in the denial of certiorari in a class action case. That case, DTD Enters., Inc. v. Wells, concerned a class action filed in New Jersey state court asserting claims against a "commercial dating-referral service." ${ }^{\prime 7}$ The claims were small, leading the New Jersey state court to order the defendant, and not the plaintiff class, to bear all of costs of notice to the absent class members. ${ }^{48}$

Here a little background is helpful. In Eisen v. Carlisle \& Jacquelin, decided shortly after the 1966 amendments to Rule 23, the Court held that Rule 23 did not authorize a federal court to order a defendant to pay for the costs of notice. ${ }^{49}$ Eisen, however, was based on the Court's interpretation of Rule 23, and did not address the issue of whether the Due Process Clause would permit the shifting of notice costs from the plaintiff to the defendant.

Arguably the Due Process Clause would allow greater flexibility, as strongly suggested by the Court in Mullane v. Central Hanover Bank \& Trust Co $^{50}$ Decided around the time of International Shoe, Mullane involved a state court aggregate proceeding created by state law to settle

\footnotetext{
46. Id. at 879. More specifically, for Justice Kennedy, due process protects "a person against having the Government impose burdens upon him except in accordance with the valid laws of the land," and "[t]his is no less true with respect to the power of a sovereign to resolve disputes through judicial process than with respect to the power of a sovereign to prescribe rules of conduct for those within its sphere." Id. (quoting in part Giaccio v. Pennsylvania, 382 U.S. 399, 403 (1966)).

47. DTD Enters., Inc. v. Wells, 130 S. Ct. 7, 7 (2009) (opinion of Kennedy, J.), cert. denied.

48. Id.

49. 417 U.S. 156, 176-79 (1974).

50. 339 U.S. 306 (1950).
} 
claims against a common trust fund trustee. ${ }^{51}$ Such "common trust funds" were authorized by state banking law to permit "donors and testators of moderately sized trusts" to join their trusts together for common administration by a corporate fiduciary. ${ }^{52}$ Thus, by sharing the costs of a corporate fiduciary, "diversification of risk and economy of management can be extended to those whose capital standing alone would not obtain such [an] advantage." ${ }^{23}$ The aggregate proceeding at issue in Mullane sought to periodically settle the liability of the corporate fiduciary to the trustees and beneficiaries of the constituent trusts, with the "decree in each such judicial settlement of accounts made binding and conclusive." 54

Mullane is commonly known for its holding that due process only required notice "reasonably calculated" to apprise the absent, nonpresent plaintiff parties of the proceedings. ${ }^{55}$ But the Court in Mullane more specifically held that the quality of the notice may be reduced if requiring more would "dissipate [the] advantages" of the underlying good the notice sought to protect, in this case the benefit of common trust fund administration. ${ }^{56}$ Thus, if some absent plaintiffs, in that case contingent beneficiaries of the small trusts administered by the common pool trustee, were too difficult or impossible to find, then due process would permit the use of newspaper notice. ${ }^{57}$ This is because individualized, mailed notice would make it economically infeasible to establish and manage common trust funds in the first place. ${ }^{58}$

The "self-defeating" rationale at the heart of Mullane strongly suggests that the permissibility of any notice procedure under the Due Process Clause depends on the impact of the procedure on the substantive objectives of the law. Under Mullane, one could sacrifice an abstract, idealized procedure like individualized notice to ensure that the interests that procedure was meant to protect (like the benefits of common trust administration) are, in fact, protected. ${ }^{59}$ Indeed, the

\footnotetext{
51. Id. at 307-09.

52. Id. at 307-08.

53. Id. at 308 .

54. Id. at 309.

55. Id. at 314 .

56. Id. at $317-18$.

57. Id.

58. Id.

59. See Owen M. Fiss, The Allure of Individualism, 78 IowA L. REv. 965, 976 (1993) (“As can be seen most clearly in his unwillingness to impose a requirement of actual notice, [Justice Jackson's] fundamental concern [in Mullane] was to render the common trust a viable financial instrument, and for that purpose, he was prepared to compromise certain individualistic values and to
} 
reasoning of Mullane could support more exotic notice procedures, like shifting the costs of notice to the defendant, to ensure that the underlying right to be free from a breach of contract was effectively enforced. ${ }^{60}$

DTD Enterprises did not implicate Eisen because it was a state court class action, but it did implicate the due process concerns addressed in Mullane. Rather than weigh the costs and benefits of a procedure based on its effect on the parties' substantive interests, as the Court did in Mullane, Justice Kennedy focused on the New Jersey court's deviation from abstract, idealized procedure. ${ }^{61}$ In particular, Justice Kennedy made clear that the money the defendant would use to pay for notice is a "property interest" that may be destroyed completely if a meritless claim is filed against the defendant, leaving it with no way to recover its costs. $^{62}$ Thus, "there is considerable force to the argument that a hearing in which the trial court does not consider the underlying merits of the class-action suit is not consistent with due process because it is not sufficient, or appropriate, to protect the property interest at stake." ${ }^{\circ 3}$

To support his conclusion that the defendant has a "property interest" in its defense costs, Justice Kennedy cited Logan v. Zimmerman Brush Co., where the Court, citing Mullane perhaps incorrectly, ${ }^{64}$ concluded that "a cause of action is a species of property protected by the ... Due Process Clause." not to pay the plaintiffs' notice costs is a similar procedural "property interest" that, as put by the Court in Logan, "the State may not finally destroy... without first giving the putative owner an opportunity to present his claim of entitlement."

But Mullane also stands for the proposition that an entitlement like a claim can be destroyed without a hearing (such as when a claimholder does not receive notice of the hearing destroying the claim) if doing so would protect the primary entitlement the claim is meant to protect.

allow what I have called a representation of interests.").

60. See id. at 977 ("In Eisen v. Carlisle \& Jacqueline, Justice Powell broke from Mullanenot Mullane's specific ruling about the insufficiency of newspaper notice, but its underlying principle.")

61. DTD Enters., 130 S. Ct. at 8.

62. Id.

63. Id.

64. See Thomas W. Merrill, The Landscape of Constitutional Property, 86 VA. L. REV. 885, 913 n.110 (2000) ("[T] right - the beneficial interest in a trust fund - and it may be that the Court was relying on the underlying trust property to satisfy the property requirement.").

65. 455 U.S. 422,428 (1982).

66. Id. at 434 . 
Indeed, despite some language suggesting an absolute entitlement to an "opportunity to be heard," 67 Mullane quite explicitly allows for the taking away of that "opportunity" when the substantive objectives of the law so dictate.

However, as with personal jurisdiction, Justice Kennedy gave short shrift to the possibility that substantive considerations may dictate abandoning a procedural right. Here Justice Kennedy's use of the language "property interest" is telling, because it invokes an entitlement to a procedure that cannot be taken away absent some sort of hearing, itself a procedural entitlement. ${ }^{68}$ Admittedly, this due process hearing could allow for the consideration of substantive concerns like the ones considered in Mullane. But Justice Kennedy did not hint at what those considerations might be apart from the merits of the underlying claim, which unduly restricts the situations where cost-shifting would be justified. For example, one can imagine situations where an inquiry into the merits for purposes of cost-shifting may be premature because the plaintiff has not had an opportunity to obtain sufficient discovery on the merits. ${ }^{69}$ In fact, by casting the procedural right as a "property right," rather than, say, a matter of judicial discretion, ${ }^{70}$ Justice Kennedy strongly suggested that no substantive considerations may exist to justify the taking of such "property."

\section{A CHANGE IN COURSE}

I have suggested so far that, as recently as 2011, Justice Kennedy adhered to a view of due process that focused on abstract procedures and ignored the impact of those procedures on the substantive entitlements they protected. However, in his most recent opinions, I perceive a change in Justice Kennedy's approach to the relationship between procedure and substance. Specifically, Justice Kennedy has recently displayed a greater sensitivity to the substantive objectives at issue in

67. See Mullane v. Central Hanover Bank \& Trust Co., 339 U.S. 305, 314 (1950) (stating that "[t]he fundamental requisite of due process of law is the opportunity to be heard.") (quoting Grannis v. Ordean, 234 U.S. 385, 394 (1914)).

68. DTD Enters., Inc. v. Wells, 130 S. Ct. 7, 8 (2009).

69. This is one of the central criticisms of Ashcroft v. Iqbal, 556 U.S. 662 (2009), a decision authored by Justice Kennedy that, in essence, permitted the dismissal of a claim based on the merits prior to discovery. See Scott Dodson, New Pleading, New Discovery, 109 Mich. L. ReV. 53, 59-68 (2010).

70. See Mark Moller, Class Action Defendants' New Lochnerism, 2012 UtAH L. Rev. 319, 322 (2012) (arguing that, historically, "judicial regulation of parties' opportunities to offer evidence was seen as a subconstitutional matter left to courts' reasoned discretion"). 
procedural cases, and, as a result, a greater willingness to adjust procedure in light of those objectives. In other words, I detect a shift from identifying and elevating an idealized picture of procedure to seeing procedure as a tool that is subservient to the substantive rights at issue.

In noting this shift, I can only speculate at the considerations that caused Justice Kennedy to take a different approach. There may be no shift at all when one considers Justice Kennedy's entire jurisprudence. But I do believe that any such shift is an important and welcome one, and for that reason alone, it is worth discussing.

\section{A. Justiciability}

One noticeable manifestation of this changing of course can be found in Hollingsworth v. Perry, which involved the constitutionality of California's Proposition 8, an amendment to the state constitution which prohibited the state from recognizing same-sex marriages. ${ }^{71}$ Proposition 8 arose as a voter-enacted ballot initiative, and thus was not proposed as legislation by the state legislature or the governor. ${ }^{72}$ It therefore came as no surprise that, after defending the constitutionality of Proposition 8 at the district court level, the governor declined to appeal the district court's ruling that Proposition 8 did, in fact, violate the U.S. Constitution. ${ }^{73}$ At issue before the Court was whether the supporters who proposed Proposition 8 and fought to get it enacted had Article III standing to appeal after the governor declined to do so. ${ }^{74}$

The Court concluded that the supporters had no standing. ${ }^{75}$ Justice Roberts, writing for the majority, took a page from both Justice Scalia in Burnham and Justice Kennedy in Nicastro by focusing on history and tradition to intuit abstract principles for allowing citizens to defend the constitutionality of a state's laws. ${ }^{76}$ At the outset, Justice Roberts noted correctly that the Court has "repeatedly held that such a 'generalized grievance,' no matter how sincere, is insufficient to confer standing.,"77 Moreover, Justice Roberts rejected the supporters' attempt to appeal on the state's behalf, citing prior Supreme Court precedent prohibiting such

\footnotetext{
71. Hollingsworth v. Perry, 133 S. Ct. 2652, 2659 (2013).

72. See id.

73. Id. at 2660.

74. Id. at $2661-63$.

75. Id. at 2668.

76. See id. at 2663-64.

77. Id. at 2662 (explaining cases supporting the proposition that a generalized grievance is insufficient to confer standing).
} 
standing. ${ }^{78}$ Justice Roberts also appealed to both formalism and tradition in the form of the Restatement (Third) of Agency to conclude that the supporters "are plainly not agents of the State- 'formal' or otherwise."79

Justice Roberts's majority opinion would seem to be right up Justice Kennedy's alley. Like in Nicastro, Justice Roberts sifted through history and tradition to arrive at an answer that had little regard for the substantive impact of that answer to the functioning of California's voter initiative system. Indeed, Justice Roberts consciously ignored a recent unanimous decision by the California Supreme Court concluding that the Proposition 8 supporters did have standing to appeal given the purpose and function of the initiative system. ${ }^{80}$ As he put it in the majority opinion, "[a]11 that the California Supreme Court decision stands for is that, so far as California is concerned, petitioners may argue in defense of Proposition 8," a position that Justice Roberts concluded "cannot override our settled law to the contrary." 81

But Justice Kennedy dissented, ${ }^{82}$ stating at the outset that the majority opinion's "reasoning does not take into account the fundamental principles or the practical dynamics of the initiative system in California ...." .83 In other words, Justice Kennedy dissented because the majority failed to consider the substantive impact of its standing decision.

The substantive impact is quite obvious when one considers how a state voter initiative system works. As put by Justice Kennedy, "[t]he very object of the initiative system is to establish a lawmaking process that does not depend upon state officials," with the goal of giving people "control of the political process" if their elected representatives are not responsive to their concerns. ${ }^{84}$ Accordingly, it would be absurd "if the very officials the initiative process seeks to circumvent are the only parties who can defend an enacted initiative when it is challenged in a legal proceeding." ${ }^{\circ 5}$ It would be doubly absurd to only permit private citizens to appeal when they receive permission from those same

\footnotetext{
78. Id. at 2667 (citing Lance v. Coffman, 549 U.S. 437, 441 (2007)).

79. Id. at $2666-67$.

80. See id. at 2660, 2666-67.

81. Id. at $2666-67$.

82. Id. at 2668 (Kennedy, J., dissenting). Justices Clarence Thomas, Samuel Alito, and Sonia Sotomayor joined the dissent. Id.

83. Id. (emphasis added).

84. Id. at 2670-71 (quoting Perry v. Brown, 265 P.3d 1002, 1016 (Cal. 2011).

85. Id. at 2671 (citations omitted).
} 
circumvented parties in accordance with the Restatement (Third) of Agency. ${ }^{86}$

Of course, Article III standing doctrine is designed to promote federal values, not state ones, but Justice Kennedy was careful to show how recognizing the standing of the proponents of Proposition 8 is consistent with the objectives of Article III standing. As Justice Kennedy noted, "[a] prime purpose of justiciability is to ensure vigorous advocacy." ${ }^{\text {"7 }}$ Indeed, one rationale for the prohibition against "generalized grievances" is that a party with only a general interest in enforcing the law will lack the motivation to develop the case. ${ }^{88}$ But, Justice Kennedy noted, the majority's decision "insists upon litigation conducted by state officials whose preference is to lose the case." 89

Justice Kennedy's approach in his dissent in Hollingsworth v. Perry is in stark contrast to his plurality opinion in Nicastro. In Nicastro, Justice Kennedy concluded that substantive considerations could never be "controlling" in determining the permissibility of a court's exercise of personal jurisdiction. ${ }^{90}$ Instead, a court may only rely upon the traditional basis for exercising personal jurisdiction over a defendantthe defendant's implied consent. ${ }^{91}$ In Hollingsworth $v$. Perry, it is Justice Roberts, not Justice Kennedy, who took that approach. In Perry, Justice Roberts concluded that substantive considerations cannot trump the traditional basis for a private citizen to represent the interests of the state - the state's consent. ${ }^{92}$

In contrast, in his Perry dissent, Justice Kennedy implicitly invoked Mullane's reasoning by concluding that substantive considerations may override traditional bases of standing if those bases would lead to selfdefeating results. ${ }^{93}$ Most obviously, requiring the authorization of the state to allow a private citizen to defend an initiative would undermine

\footnotetext{
86. See id. at 2671-72.

87. Id. at 2674.

88. Lea Brilmayer, The Jurisprudence of Article III: Perspectives on the "Case or Controversy” Requirement, 93 HARV. L. REV. 297, 306 (1979) (noting effect of ideological plaintiff on rights of those injured). Hollingsworth v. Perry did not implicate the separation-of-powers concerns that justify the prohibition against generalized grievances, as it involved the defense of a state law, and not the enforcement of federal law. See Lujan v. Defs. of Wildlife, 504 U.S. 555, 577 (1992) (noting that recognizing standing for generalized harm "is to permit Congress to transfer from the President to the courts the Chief Executive's most important constitutional duty, to 'take Care that the Laws be faithfully executed."') (quoting U.S. CONST. art. II, § 3)).

89. Perry, 133 S. Ct. at 2674 (Kennedy, J., dissenting).

90. J. McIntyre Mach., Ltd. v. Nicastro, 564 U.S. 873, 885-86 (2011).

91. See id. at 881

92. Perry, 133 S. Ct. at 2666 (Roberts, C.J., majority).

93. See id. at 2671 (Kennedy, J., dissenting).
} 
the very point of California's voter initiative - to permit citizens to pass that very same initiative without the state's authorization. ${ }^{94}$ But more importantly, Justice Kennedy pointed out that requiring state authorization would undermine a primary purpose of Article III standing doctrine itself, by ensuring the absence of any "vigorous advocacy" because the only party allowed to defend the initiative has no incentive to do so. ${ }^{95}$

Arguably, one should not read too much into Justice Kennedy's dissent in Perry. As an initial matter, Justice Kennedy, as a native Californian, was probably especially knowledgeable and protective of the state's voter initiative system. More importantly, in a companion case involving the federal Defense of Marriage Act (DOMA), United States $v$. Windsor, Justice Kennedy concluded that standing was present even though, like the governor in Perry, the United States had no actual interest in defending the constitutionality of DOMA. ${ }^{96}$ There, Justice Kennedy noted that the United States nevertheless continued to enforce DOMA, and thus concluded that there was an actual dispute despite the United States' admittedly half-hearted enforcement. ${ }^{97}$ In addition, Justice Kennedy concluded that the lack of adversity was not a problem because such adversity is only a prudential requirement, and that a vigorous defense can be assured in this case through the use of amici. ${ }^{98}$ Finally, Justice Kennedy stressed that "the merits question ... is one of immediate importance to the Federal Government and to hundreds of thousands of persons." 99

Like in Perry, Justice Kennedy in Windsor displayed a sensitivity to the substantive impact of his justiciability ruling. However, Justice Kennedy did not give the same care to Article III values that he did in Perry. Whereas, in Perry, he noted the importance of standing requirements in ensuring "vigorous advocacy," in Windsor, Justice Kennedy relegated adversity, a precondition for vigorous advocacy, to merely a "prudential" concern, and was perhaps too hasty in concluding that amici could pick up the slack. Thus, Justice Kennedy's opinion in Windsor appeared less like a considered balancing of interests and more like an attempt to reach the merits by any means necessary.

\footnotetext{
94. See id. at $2673-75$.

95. Id. at 2674.

96. United States v. Windsor, 133 S. Ct. 2675, 2684 (2013) (noting that "the President... instructed the Department [of Justice] not to defend the statute in Windsor").

97. Id. at 2686-87.

98. Id. at 2687-88.

99. Id. at 2689 .
} 


\section{B. Class Actions}

The shift evidenced by Justice Kennedy in Perry would take some time to manifest itself in the class action context. Consider, for example, American Express Co. v. Italian Colors Restaurant, decided only several days before Perry, where the Court addressed whether a class action waiver in an arbitration agreement would frustrate the enforcement of federal antitrust law, particularly for claims that are too small and costly to litigate in individual actions. ${ }^{100}$ Justice Scalia, writing for a majority that included Justice Kennedy, concluded that the policies of antitrust enforcement did not bar the use of a class action waiver. ${ }^{101}$ Among other things, the Court noted the "usual rule that litigation is conducted by and on behalf of the individual named parties only," and thus antitrust policy cannot frustrate an "agree[ment] to arbitrate pursuant to that 'usual rule,' and it would be remarkable for a court to erase that expectation." 102 Here the abstract, idealized picture of procedure that motivated Burnham and Nicastro resurfaced yet again.

But Italian Colors can be explained, in part, by the influence of Justice Scalia on the Court's class action jurisprudence. In fact, Justice Scalia has authored most of the Court's recent class action decisions, and in those decisions, he has stressed that the class action is "an exception to the usual rule that litigation is conducted by and on behalf of the individual named parties only." 103 But Justice Scalia passed away on February 13, 2016. ${ }^{104}$ And in the Court's first class action decision after his death, Justice Kennedy not only took charge, but provided an alternative, functional account of the class action in line with his own thoughts in Perry.

That case, Tyson Foods, Inc. v. Bouaphakeo, involved a class action of meat processing workers seeking overtime for the time spent "donning and doffing" protective gear. ${ }^{105}$ Under the Fair Labor Standards Act (FLSA), a qualified worker is entitled to receive overtime if he or she

\footnotetext{
100. Am. Express Co. v. Italian Colors Rest., 133 S. Ct. 2304, 2308 (2013).

101. See id. at 2309-10.

102. Id. at 2309 (citation omitted)

103. Wal-Mart Stores, Inc. v. Dukes, 564 U.S. 338, 348 (2011) (quoting Califano v. Yamasaki, 442 U.S. 682, 700-01 (1979)).

104. Adam Liptak, Antonin Scalia, Justice on the Supreme Court, Dies at 79, N.Y. TimES, Feb. 14, 2016, at A1.

105. 136 S. Ct. 1036, 1041 (2016). Tyson involved both a Rule 23 class action and a "collective action" under the Fair Labor Standards Act. Id. at 1042. For purposes of this essay, I will focus on the Rule 23 class action.
} 
works in excess of forty hours in a week. ${ }^{106}$ The workers contended that any overtime calculation should include the time each worker spent "donning and doffing." "107 However, the employer, Tyson Foods, failed to keep any records of those times. ${ }^{108}$ For that reason, the workers invoked Anderson v. Mt. Clemens Pottery Co., decided in 1946, in which the Supreme Court held that, in the absence of time records, a worker seeking overtime pay may use representative evidence of other workers to support an inference of the amount owed. ${ }^{109}$

The issue before the Court in Tyson was whether the plaintiffs could use such representative evidence in a Rule 23 class action. ${ }^{110}$ Again, some background is helpful. In 2011, the same year the Court decided Nicastro, the Court in Wal-Mart Stores, Inc. v. Dukes reviewed the certification of a large-scale employment discrimination class action. ${ }^{11}$ There, the district court, among other things, approved the use of a procedure to determine the backpay owed to the class by first 1) trying a small sample of cases before a special master and then 2) using the results of those cases to determine the backpay for the entire class. ${ }^{12}$

In a majority opinion written by, of course, Justice Scalia and joined by Justice Kennedy, the Court rejected this use of what it called a "Trial by Formula."113 Echoing Justice Kennedy's concerns in DTD Enterprises, the Court concluded that because of such a procedure, "WalMart w[ould] not be entitled to litigate its statutory defenses to individual claims." $" 114$

Curiously, unlike Justice Kennedy in DTD Enterprises, the Court did not see this restriction on the defendant's procedural rights as a due process concern. Instead, the Court invoked the Rules Enabling Act, which prohibits any rule of civil procedure from "abridg[ing], enlarg[ing], or modify[ing] any substantive right." ${ }^{\text {115 }}$ Presumably, using Rule 23 to certify a class employing such a sampling procedure would violate the Rules Enabling Act because Rule 23 would allow for the

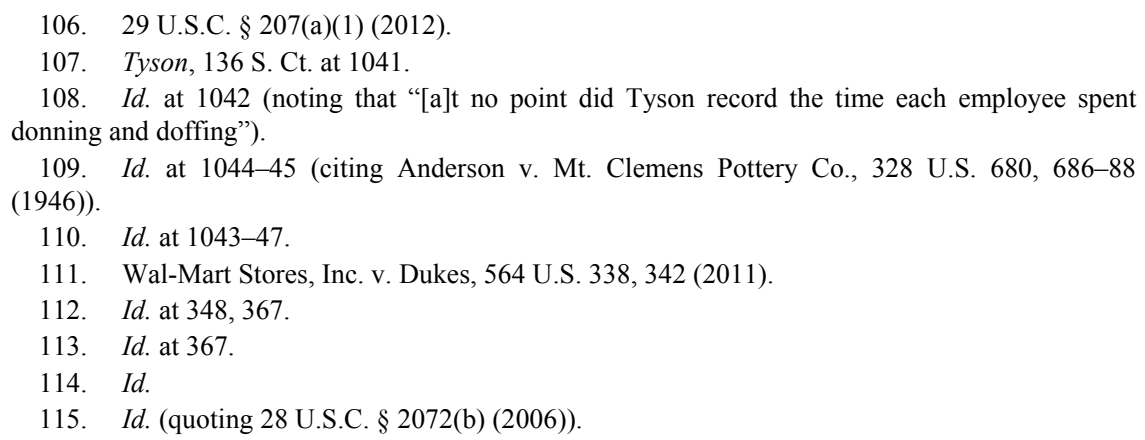


"abridg[ing]" of the defendant's "substantive right" to assert statutory defenses. Accordingly, just as Justice Kennedy in DTD Enterprises viewed the right to a defense as a "property interest" for due process purposes, Justice Scalia in Wal-Mart viewed the right to assert an individual defense as a "substantive right" that cannot be curtailed by Rule $23 .^{116}$

This view that certain procedural rights are "property interests" or "substantive rights" that cannot be trumped by other considerations poses an existential threat to the class action itself. As noted by Justice Scalia in his majority opinion in Wal-Mart, the class action is "an exception to the usual rule that litigation is conducted by and on behalf of the individual named parties only." "Accordingly, as evidenced by WalMart, the Court has been hostile to any attempt to use the class action to fundamentally deviate from the procedures that would be used in litigation conducted by the class members themselves. But this hostility has the potential to destroy the class action, insofar as this hostility may lead to a prohibition on any deviation from the procedures used in individual litigation.

Indeed, in a case decided two years after Wal-Mart, Comcast Corp. v. Behrend, the Court, in a majority opinion authored by (who else) Justice Scalia and joined by Justice Kennedy, suggested, without deciding, that a class action cannot be certified at all if it does not involve an accurate procedure to determine the individual damages of each class member. ${ }^{118}$ Such a holding would have the effect of banning almost all class actions involving damage claims because it would require individual hearings on damages absent proof that the hearings were clearly unnecessary. Again, individual hearings are the ideal, and the ideal threatened to extinguish the class action exception entirely.

The use of representative evidence in Tyson implicated both $\mathrm{Wal}$ Mart and Comcast. In Tyson, the class used an expert to measure the doffing and donning times of representative workers to arrive at an average time to be used for segments of the class as a whole. ${ }^{119}$ Then the class employed another expert to use those averages to determine what

\footnotetext{
116. See id.

117. Id. at 348 (quoting Califano v. Yamasaki, 442 U.S. 682, 700-01 (1979)).

118. See Comcast Corp. v. Behrend, 133 S. Ct. 1426, 1434-35 (2013).

119. Tyson Foods, Inc. v. Bouaphakeo, 136 S. Ct. 1036, 1043 (2016) (noting that the expert "conducted 744 videotaped observations and analyzed how long various donning and doffing activities took. He then averaged the time taken in the observations to produce an estimate of 18 minutes a day for the cut and retrim departments and 21.25 minutes for the kill department.").
} 
percentage of the class qualified for overtime. ${ }^{120}$ This procedure did not allow the employer Tyson to assert individual defenses against specific class members, at least not at this stage of the proceedings, and thus was clearly in tension with Wal-Mart. ${ }^{121}$

Moreover, there was considerable variance on the donning and doffing times across the workers. Some took seconds, while others took as much as nine minutes. ${ }^{122}$ There was also variance among the workers as to who would be entitled to overtime pay if the donning and doffing times were added. ${ }^{123}$ Thus, there was a risk that some class members would get inaccurate damages based on these averages, which would be in clear tension with Comcast. Indeed, there was a risk that some of the class members would not be entitled to overtime at all and thus were completely uninjured, raising the issue of whether some class members even had standing to sue. ${ }^{124}$

Given these difficulties, one could imagine Justice Kennedy joining an opinion holding that the use of such representative evidence by the experts in Tyson made class certification inappropriate. Indeed, one could also imagine the Court firmly holding what it hinted at in both Wal-Mart and Comcast - that a class action involving individualized remedies cannot be certified at all because it would depart too much from the ideal procedure of individualized hearings.

But, as with Hollingsworth v. Perry, Justice Kennedy in Tyson took a different approach. Justice Kennedy first expressed a sensitivity to the substantive impact of any decision by the Court by stating up front that "the Court would reach too far were it to establish general rules governing the use of statistical evidence, or so-called representative evidence, in all class-action cases." 125 Then Justice Kennedy turned to the use of representative evidence in FLSA overtime cases, noting that the Court in Mt. Clemens permitted such evidence because "the 'remedial nature of [the FLSA] and the great public policy which it embodies... militate against making' the burden of proving uncompensated work 'an impossible hurdle for the employee." "126 Thus, rather than focus on any deviation of abstract, idealized procedures to the

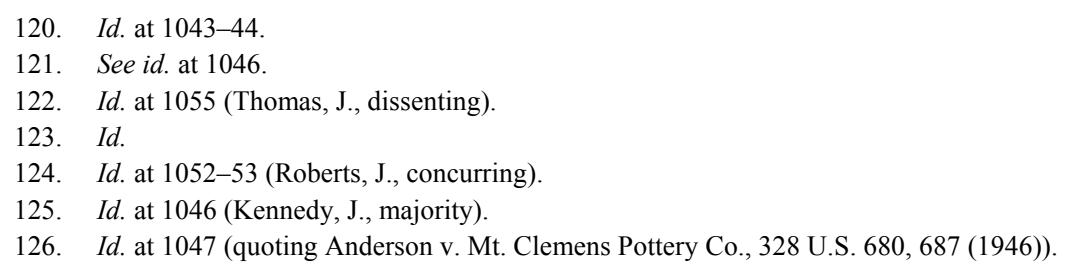


exclusion of substantive concerns, Justice Kennedy put substantive concerns at the forefront.

Justice Kennedy then concluded that the use of representative evidence was permissible in this case for two reasons. It is important to spend some time on the first reason to fully understand the second reason. As to the first reason, Justice Kennedy distinguished Wal-Mart from this case by noting that, unlike in Wal-Mart, such representative evidence was permissible as a matter of law in individual cases as articulated in Mt. Clemens. ${ }^{127}$ Thus, the use of such representative evidence in a class action was not a deviation from individual cases but actually consistent with such cases. Indeed, Justice Kennedy went further to suggest that permitting the use of representative evidence in individual actions but not in class actions "would ignore the Rules Enabling Act's pellucid instruction that use of the class device cannot 'abridge . . a any substantive right.", 128

This first reason is remarkable. Earlier, I noted that the Court's views of the Rules Enabling Act in Wal-Mart posed an existential threat to the class action. This is because the Court in Wal-Mart suggested that the procedures used in individual hearings, such as a party's ability to assert affirmative defenses, were seen as "substantive rights" that one cannot deviate from, and the class action is by definition a deviation from those procedures. But Justice Kennedy in Tyson did not consider the class action an exception to an ideal, but put it on equal footing with individual proceedings. In fact, Justice Kennedy concluded that it would be a violation of the Rules Enabling Act not to permit a class action to use representative evidence if such evidence is permissible in an individual action. ${ }^{129}$

Arguably Justice Kennedy was able to put the class action on equal footing with an individual action because the individual action itself was a deviation from the norm. But it is unclear why the vision of procedure at the heart of Comcast and Wal-Mart would permit such a deviation even in an individual proceeding. If a party cannot assert an individual defense because of the use of average awards, then a party cannot not do so in either an individual action or a class proceeding.

In other words, a commitment to the vision of ideal procedure in Comcast and Wal-Mart would not use the Mt. Clemens ruling to support the use of representative evidence in class actions. Instead, it would

\footnotetext{
127. Id. at 1048-49.

128. Id. at 1046 (quoting 28 U.S.C. $\S 2072$ (b) (2006)).

129. Id.
} 
question the continuing validity of Mt. Clemens itself, or at least Justice Kennedy's interpretation of it. And that is precisely what Justice Thomas did in his Tyson dissent, noting that the majority not only misinterpreted Mt. Clemens, ${ }^{130}$ but that "[t]he majority's reliance on Mt. Clemens is questionable given that decision's shaky foundations."131

But I do not think that Justice Kennedy is simply piggybacking off of the Court's precedent in Mt. Clemens. Instead, I see Justice Kennedy as changing the relevant "substantive right" for Rules Enabling Act purposes. By invoking "the "remedial nature of [the FLSA] and the great public policy which it embodies,"132 I take Justice Kennedy as placing the right to overtime pay as the relevant "substantive right," not the procedures used to obtain it. This would explain why Justice Kennedy placed the class action on equal footing with individualized proceedings. Both are simply different tools for achieving the "great public policy" of the FLSA.

In my view, Justice Kennedy's second reason for permitting representative evidence in Tyson can only be understood in light of this suggested shift in the relevant "substantive right." As for his second reason, Justice Kennedy concluded that Tyson Foods itself may be responsible for the problems it identified. For example, in Justice Kennedy's view, Tyson Foods could not assert individual defenses because it failed to keep records in the first place, and thus "there were no alternative means for the employees to establish their hours worked" other than through representative evidence. ${ }^{133}$ Thus, Tyson Foods's only recourse was to question the admissibility of the class's representative evidence. However, because Tyson Foods consistently objected to the very existence of the class action, it failed to challenge the admissibility of the expert reports at trial. ${ }^{134}$

Moreover, Justice Kennedy pointed out that, prior to trial, the class actually proposed to bifurcate proceedings, which would allow a court to

130. Id. at 1058 (Thomas, J., dissenting) (noting that "the majority today goes beyond what Mt. Clemens held").

131. Id. at 1057.

132. Id. at 1047 (Kennedy, J., majority) (quoting Anderson v. Mt. Clemens Pottery Co., 328 U.S. 680, 687 (1946)).

133. Id.

134. See id. at 1047, 1049 ("Petitioner, however, did not raise a challenge to respondents' experts' methodology under Daubert; and, as a result, there is no basis in the record to conclude it was legal error to admit that evidence."); see also id. at 1044 ("Instead, as it had done in its opposition to class certification, [Tyson Foods] argued to the jury that the varying amounts of time it took employees to don and doff different protective equipment made the lawsuit too speculative for classwide recovery."). 
resolve common issues in a common proceeding and then resolve individual issues in separate hearings. ${ }^{135}$ Thus, such a bifurcation procedure would allow for both a class action and the very individual procedures that Tyson Foods argued it was entitled to. However, Tyson Foods opposed the proposed bifurcation below, and Justice Kennedy noted that Tyson Foods "now seeks to profit from the difficulty it caused," suggesting, without concluding, that any difficulties encountered by Tyson Foods in identifying uninjured defendants may be "invited." "136

Justice Kennedy's second reason for permitting the use of representative evidence would not make sense if he fully accepted the view of abstract, idealized procedure at the heart of both Wal-Mart and Comcast. In Wal-Mart, the right to assert affirmative defenses is a "substantive right" full stop. ${ }^{137}$ Accordingly, why would Tyson Foods have any obligation to challenge the admissibility of the expert reports or accept bifurcation if such procedures are less than what Tyson Foods was fully entitled to?

But Justice Kennedy's second reason does make sense if the relevant "substantive right" was not the procedures, but the entitlement the procedures are designed to protect. If the relevant "substantive right" is, in fact, the "remedial nature" of the FLSA, then Tyson Foods looks less like a party seeking to fully vindicate their rights than a party seeking to manipulate procedure to avoid paying the overtime it owed.

Again, the spirit of Mullane's "self-defeating" principle permeates Justice Kennedy's reasoning here. Protecting Tyson Foods's "property interest" in individualized procedures would provide a blueprint for employers to avoid paying overtime to its employees, thereby undermining the very objectives of the FLSA and the rights of action it provides. Thus, rather than allow employers to profit from failing to keep records and rejecting compromise measures like bifurcation, Justice Kennedy (at least in my view) would prefer deviating from ideal procedures to ensure that the workers' right to overtime pay is protected.

Finally, I do not think that Justice Kennedy's joining of the opinion in Spokeo, Inc. v. Robins undermines this shift. ${ }^{138}$ Spokeo, which was decided shortly after Tyson, concerned whether a plaintiff asserting a class action had standing to sue Spokeo, Inc., an information retrieval

\footnotetext{
135. Id. at 1050 .

136. Id.

137. Supra notes $115-16$ and accompanying text.

138. 136 S. Ct. 1540 (2016).
} 
service, for violating the Fair Credit Reporting Act (FCRA). ${ }^{139}$ The plaintiff alleged that Spokeo provided inaccurate information about the plaintiff and that Spokeo thereby violated his statutory rights to notice of these inaccuracies as outlined in the FCRA. ${ }^{140}$ The district court concluded that the plaintiff lacked standing, but the Ninth Circuit reversed, concluding that the plaintiff had asserted a "particularized" injury as to him alone. ${ }^{141}$

The Court, in a majority opinion written by Justice Alito and joined by Justice Kennedy, concluded that the Ninth Circuit's analysis was incomplete because it did not do a separate inquiry as to whether the harm was "concrete." 142 In so holding, Justice Alito's opinion alluded to the abstract approach taken by Justice Scalia in Burnham by noting that "whether an intangible harm constitutes injury in fact, both history and the judgment of Congress play important roles."143 But Justice Alito began by discussing the functions of standing, noting that the doctrine "serves to prevent the judicial process from being used to usurp the powers of the political branches." "144 Thus, despite the appeals to history and tradition, functional considerations remained front and center.

Moreover, the outcome of the Court's decision is not as antisubstantive as it first appears. Admittedly, the Court, in effect, reversed the Ninth Circuit's conclusion that there was sufficient standing to sue, and thus appears to frustrate the private enforcement of the FCRA. But the Court's reversal can be easily justified by the functionalist concerns that animated Justice Kennedy's dissent in Perry. In particular, Justice Alito's opinion noted that a violation of a statutory right to a procedure, in this case the reporting procedures of the FCRA, "may result in no harm." "145 Although unstated, this independent inquiry into harm can be justified as ensuring the "vigorous advocacy" that Justice Kennedy called a "prime purpose of justiciability" of standing in Perry. ${ }^{146}$ That vigorous advocacy is all the more important in a class action, where many of the class members are not present to assert their claims. Indeed, it is worth noting that Justice Ginsburg's dissent, joined by Justice Sotomayor, only

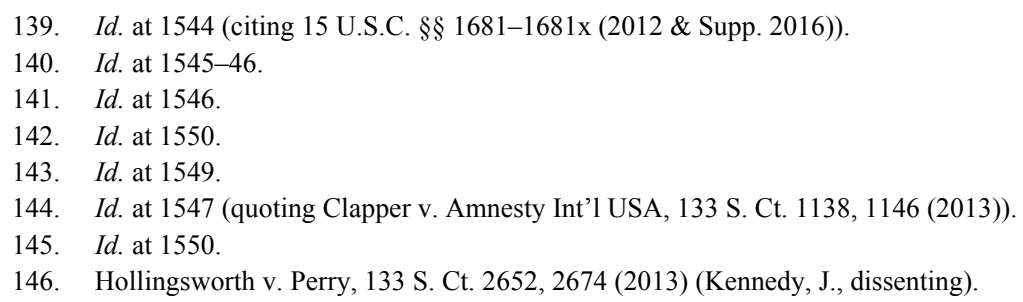


faulted the majority for choosing to remand when it could have very easily found that the alleged injury was sufficiently concrete. ${ }^{147}$

\section{CONCLUSION}

Again, I can only speculate as to the causes of this shift in Justice Kennedy's views, and some of my speculations pepper the analysis above. Moreover, given my sample size of cases, I am willing to concede that any shift I perceive may be illusory. But I believe that it is real, and there is some evidence of this shift even in Justice Kennedy's recent decisions on race, ${ }^{148}$ the very decisions that presumably inspired his remarks supporting a judge's changing course over time. ${ }^{149}$ And if it is real, I would argue that it is a shift worth celebrating, because it would mark a return to the functionalist roots of the 1966 amendments that gave rise to Rule 23.

147. Spokeo, $136 \mathrm{~S}$. Ct. at 1555-56 (Ginsburg, J., dissenting). As this was going to press the Court decided Microsoft v. Baker, No. 15-457 (U.S. Sup. Ct. June 12, 2017), in which the Court concluded that federal courts lacked appellate jurisidiction over a denial of class certification that lead to a voluntary dismissal of the underlying claims. Admittedly, Justice Kennedy's support for the majority holding may provide counterevidence against a shift, but the complexity of the case makes such a conclusion far from certain, and I hope to address this case in future writing.

148. Compare, for example, Justice Kennedy's views concerning voluntary efforts to avoid disparate impact liability for Title VII claims in Ricci v. DeStefano, 557 U.S. 557 (2009), with his majority opinion supporting disparate impact liability for Fair Housing Act claims in Texas Department of Housing and Community Affairs v. Inclusive Communities Project, Inc., $135 \mathrm{~S}$. Ct. 2507 (2015).

In Ricci, Justice Kennedy, writing for a majority, concluded that a city fire department cannot provide preferential treatment to minority applicants to avoid disparate impact liability under Title VII unless the city "can demonstrate a strong basis in evidence that, had it not taken the action, it would have been liable under the disparate-impact statute." Ricci, 557 U.S. at 563. As put by Justice Kennedy, "[w]hatever the City's ultimate aim - however well-intentioned or benevolent it might have seemed - the City made its employment decision because of race." Id. at 579-80. Thus, in Ricci, Justice Kennedy takes a formalistic view of the racial discrimination prohibited by Title VII.

In contrast, in Inclusive Communities, Justice Kennedy, again writing for a majority, concluded that the Fair Housing Act permitted disparate impact claims, noting that "[r]ecognition of disparate-impact claims is consistent with the FHA's central purpose," which is to prohibit "unlawful practices" such as "zoning laws and other housing restrictions that function unfairly to exclude minorities from certain neighborhoods without any sufficient justification." Inclusive Cmtys, 135 S. Ct. at 2521. But, as Justice Thomas, in dissent, pointed out, by permitting such disparate impact liability, "parties fearful of disparate-impact claims may let race drive their decisionmaking in hopes of avoiding litigation altogether," the very conduct the Court sought to curtail in Ricci. See id. at 2550 (Thomas, J., dissenting) (citing Ricci). The decisions are not inconsistent, but Justice Kennedy's formal conception of racial discrimination in Ricci seemed to be less of a preoccupation for him when he considered the facially neutral "zoning laws and other housing restrictions" that function to exclude racial minorities in Inclusive Communities.

149. Mark Sherman, Justice: Changing Course on the Bench Is Not Weakness, APNEWS.COM (Sept. 23, 2016), https://apnews.com/93476b06b78c409393f38df4d5d507b7. 
It is worth pointing out why such a return is worth celebrating. The abstract, idealized procedure approach found in such cases as Justice Scalia's plurality in Burnham, Justice Kennedy's own plurality opinion in Nicastro, Justice Roberts's majority opinion in Hollingsworth $v$. Perry, and Justice Scalia's majority opinion in Wal-Mart has a number of advantages. Such an approach can protect against judges using vague notions of "fairness" to impose their own subjective preferences. ${ }^{150}$ It can also take advantage of the wisdom of the past. There are usually good reasons why certain traditional procedures persist and others do not. But a too-rigid approach can lead not only to suboptimal results, but, as recognized in Mullane and in Justice Kennedy's opinions in Perry and Tyson, it can lead to results that may undermine the very rights and objectives justifying those procedures.

This concern with the suboptimal and oftentimes self-defeating disadvantages of focusing solely on abstract procedure at the expense of substance certainly animated the 1966 amendments to Rule 23 . The advisory committee notes to the 1966 amendments pointed out that the prior rule sought to be "defined in terms of the abstract nature of the rights involved," resulting in a rule that, among other things, was "obscure and uncertain" and that did not "provide an adequate guide to the proper extent of the judgments in class actions." 151 For the 1966 amendments, in contrast, "[t]he reform of Rule 23 was intended to shake the law of class actions free of abstract categories ... and to rebuild the law on functional lines responsive to those recurrent life patterns which call for mass litigation through representative parties."152

One could argue that the 1966 amendments was not quite successful in crafting a rule responsive to substantive concerns. ${ }^{153}$ But in being sensitive to "those recurrent life patterns which call for" class treatment, the 1966 amendments produced a class action rule that has been quite useful, and has the potential to be more useful still. ${ }^{154}$

Accordingly, I agree wholeheartedly with Justice Kennedy's view that the questioning of premises is a sign of a judge's fidelity to the law.

150. See Burnham v. Superior Court of Cal., 495 U.S. 604, 623 (1990) (criticizing the "subjectivity, and hence inadequacy" of using fairness considerations in determining whether the exercise of personal jurisdiction comports with the Due Process Clause).

151. FED. R. CIV. P. 23 advisory committee's note to 1966 amendment; 39 F.R.D. 69 (1966).

152. Kaplan, supra note 3, at 497. Ben Kaplan was the reporter to the 1966 amendments. Id.

153. See Robert G. Bone, Walking the Class Action Maze: Toward a More Functional Rule 23, 46 U. MiCH. J.L. REFORM 1097, 1102-05 (2013) (making this argument).

154. Kaplan, supra note 3, at 497, and accompanying text; see also Sergio J. Campos, Mass Torts and Due Process, 65 VAND. L. REV. 1059, 1076-79 (2012) (arguing for a more expansive interpretation of Rule 23). 
This is because a willingness to abandon tradition in the face of selfdefeating consequences represents the right kind of fidelity - a fidelity to the purposes and objectives of the law rather than its forms and traditions. And, as far as I can tell, Justice Kennedy practices what he preaches. 